\title{
Sensitivity to House Dust Mites Allergens in Patients with Allergic Asthma in Erzincan Province, Turkey
}

\author{
Erzincan’ da Alerjik Astımlı Hastaların Ev Tozu Akar Alerjenlerine Karşı Duyarlılığı̆
}

\author{
Erhan Zeytun', Salih Doğan'1 , Fatih Özçiçek², Edhem Ünver ${ }^{3}$ \\ 'Department of Biology, Erzincan University Faculty of Arts and Sciences, Erzincan, Turkey \\ 2Department of Internal Medicine, Erzincan University School of Medicine, Erzincan, Turkey \\ ${ }^{3}$ Department of Chest Disease, Erzincan University School of Medicine, Erzincan, Turkey
}

\section{ABSTRACT}

Objective: To investigate the sensitivity of allergic asthma (AA) patients to house dust mites (HDM) by conducting skin tests, measuring total and specific IgE antibodies to Dermatophagoides pteronyssinus and D. farinae mites, and examining HDM fauna in patients' homes. Methods: The study included 25 patients with AA and 31 healthy controls, who were challenged with Der $p$ and Der $f$ allergens; serum levels of allergen-specific lgE and total IgE were measured. Dust samples were collected from the homes of all participants, and mite species and the number of mites per gram of dust were investigated.

Results: D. pteronyssinus was found in the homes of $94.7 \%$ patients with positive Der $p$ reactions in the skin test $(p<0.001)$. D. farinae was found in the homes of $22.2 \%$ patients with positive Der f reactions in the skin test ( $p>0.05$ ). D. pteronyssinus-specific lgE was detected in $75 \%$ patients in whose homes $D$. pteronyssinus was also found, while $D$. farinae-specific lgE was detected in $16.6 \%$ patients in whose homes $D$. farinae was also found.

Conclusion: A part of AA patients residing in Erzincan are sensitive to HDM allergens, and high numbers of mites leading to allergic sensitization are found in their homes.

Keywords: Allergic asthma, skin prick test, specific lgE, Dermatophagoides pteronyssinus, Dermatophagoides farinae

Received: 23.08.2016

Accepted: 28.12 .2016

\section{Öz}

Amaç: Alerjik astımlı (AA) hastaların ev tozu akarlarına (ETA) karşı olan duyarlılığını deri testi ile değerlendirmek, hastaların Dermatophagoides pteronyssinus ve Dermatophagoides farinae'ye karşı spesifik IgE ve total IgE antikorlarını ölçmek ve hasta evlerindeki toz akar faunası araştırmak amaçlandı.

Yöntemler: Çalışmaya Der p ve Der fakar alerjenleri ile deri testi yapılan AA’ı 25 hasta ve 31 sağlıkı kontrol alındı ve kan serumunda alerjene özgü lgE ve total IgE seviyeleri ölçüldü. Tüm katılımcıların evlerinden toz örnekleri toplanarak gram tozdaki akar sayısı ve türleri bakımından incelendi.

Bulgular: Deri testinde pozitif Der $p$ reaksiyonu görülen hastaların \%94,7'sinin evinde Dermatophagoides pteronyssinus ( $<<0,001$ ), pozitif Der $\mathrm{f}$ reaksiyonu görülen hastaların \%22,2'sinin evinde Dermatophagoides farinae tespit edildi. Spesifik IgE sonuçlarına göre Der p duyarlılı̆ı saptanan hastaların \%75'inin evinde D. pteronyssinus, Der f duyarlılığı saptanan hastaların ise \%16,6'sının evinde D. farinae tespit edildi.

Sonuç: Erzincan'daki AA'lı hastaların bir kısmının ev tozu akar alerjenlerine karşı duyarlı oldukları ve hasta evlerinin alerjik duyarlanmaya yol açan akarları yüksek oranda barındırdığı görüldü.

Anahtar Kelimeler: Alerjik astım, deri prick testi, spesifik lgE, Dermatophagoides pteronyssinus, Dermatophagoides farinae Geliş Tarihi: 23.08.2016

Kabul Tarihi: 28.12.2016

This study which is based on the doctoral dissertation of the first author was presented at the International Congress on Applied Biological Sciences, 16-20 September 2015, Skopje, Macedonia.

ilk yazarın doktora tezine dayanan bu çalışma, Uluslararası Uygulamalı Biyolojik Bilimler Kongresi'nde sunulmuştur, 16-20 Eylül 2015, Üsküp, Makedonya.

Address for Correspondence / Yazışma Adresi: Erhan Zeytun E.mail: erhanzeytun24@gmail.com DOI: 10.5152/tpd.2017.5059

CCopyright 2017 Turkish Society for Parasitology - Available online at www.tparazitolderg.org

CTelif hakkı 2017 Türkiye Parazitoloji Derneği - Makale metnine www.tparazitolderg.org web sayfasından ulaşılabilir. 


\section{INTRODUCTION}

Allergic asthma (AA) is a chronic disease of the lower respiratory tract that is characterized by narrowing of the bronchi and inflammation of the bronchial mucosa in which numerous cells and mediators, mainly mast cells, T lymphocytes, and eosinophils, play a role (1). AA manifests as chronic inflammation, wheezing, particularly at night, shortness of breath, chest tightness, and coughing attacks. While its prevalence varies among countries depending on the respiratory allergen load, it affects about 1\%-18\% of the population worldwide, particularly children. It is a social and economic burden on communities and causes significant absence from school and work $(2,3)$.

House dust mites (HDMs), particularly the cosmopolitan species Dermatophagoides pteronyssinus, D. farinae, and Euroglyphus maynei from the family Pyroglyphidae (Astigmata: Acari), may cause atopic diseases known as HDM allergy or HDM atopy in humans. These include allergic rhinitis, atopic dermatitis (eczema), and allergic conjunctivitis. HDMs are the major sources of indoor inhalant allergens facilitating both sensitization of atopic subjects and asthmatic (atopic) attacks in patients. The most common and effective HDM allergens are Der $p$ and Der $f$, which are the major allergens of $D$. pteronyssinus and $D$. farinae. The allergens are released into the environment through mite feces, which are residues of digestion and contain enzymes, such as peptidase, protease, transferase, and glucosidase (4-7). On an average, an HDM defecates up to 20 times a day. Over time, mite feces and tissue residues arising from fragmentation after death accumulate in carpets, fabric-covered furniture, furry toys, mattresses, and pillows and allergens mix with indoor air. Inhalation of these allergens stimulates the immune system in the respiratory mucosa and causes the initial allergic sensitization mediated by specific IgE. Upon subsequent contact with the allergens, predisposed patients react to the mediators, which are mainly derived from mast cells, causing vasodilation in the bronchial mucosa, edema, mucus secretion, and bronchospasm, leading to acute inflammatory episodes (7-9).

To better understand the etiology of AA and allergic sensitization, it is essential to investigate patients' homes for HDM and to concomitantly conduct skin and serological tests (10-18).

The aim of this study was to investigate AA patients' homes for HDMs that are sources of the allergens Der $p$ and Der $f$ and to compare it with the results of skin and serological tests.

\section{METHODS}

\section{Patients and study plan}

The study included 25 patients residing in Erzincan Province, who presented to the departments of chest diseases or internal medicine at the training hospital and were diagnosed with AA between March 2014 and June 2014, based on the Global Initiative for Asthma (GINA) criteria (3). The control group comprised 31 healthy individuals without allergic symptoms. The clinical examination of patient and control groups as well as skin and serological testings were carried out in the training hospital, while the Department of Biology collected and examined the dust samples from patients' homes. The Erzincan University Ethics Committee approved the study (Decision No: 2014/2-6), and all the participants provided written informed consent.

\section{Skin Prick Test (SPT)}

The interior surface of the forearm was chosen as the test area and cleaned with alcohol. Using sterile lancets (Oryum; İstanbul, Turkey), physiological saline solution was applied to the test area as negative control, and $10 \mathrm{mg} / \mathrm{mL}$ of histamine dihydrochloride was applied as positive control. Der $p$ and Der f (Lofarma; Milano, Italy) solutions were used as HDM allergens. The evaluation was conducted by examining the controls after 15-20 min, and indurations of $\geq 3 \mathrm{~mm}$ were considered positive (19).

\section{Serological tests}

From each patient and each control, $5 \mathrm{~mL}$ of venous blood was collected and centrifuged to separate the serum. The levels of Der $p$ and Der $f$ allergen-specific IgE were measured using the immunblot method with a Rida X Screen device and kit (R-Biopharm AG; Darmstadt, Germany), while the total IgE level was determined using the chemiluminescence immunoassay (CLIA) method with a Siemens Immulite 2000 XPI device and kit (Siemens Healthcare Diagnostic; UK). For evaluation, specific IgE levels of $\geq 0.35 \mathrm{kUA} / \mathrm{L}$ and total $\mathrm{lg} E$ values of $\geq 87 \mathrm{U} / \mathrm{mL}$ were considered positive.

\section{Collection and examination of dust samples}

The dust samples were collected during the period of April 2014 to June 2014 from the carpets, fabric-covered furniture, mattresses, and pillows in the homes of 25 patients and 31 controls from various neighborhoods of Erzincan Province by applying vacuum for $2 \mathrm{~min} / \mathrm{m}^{2}$ using a vacuum cleaner (Bosch; München, Germany). A separate dust bag was used for each house, and the hose and pipe stub of the vacuum cleaner were removed and cleaned between each dust collection. The dust samples were placed in sealed plastic bags and brought to the laboratory within $6 \mathrm{~h}$. The samples were dry sieved using sieves with meshes of sizes $1.5 \mathrm{~cm}$ and $1 \mathrm{~cm}$, with the small-sized mesh being placed beneath the large-sized mesh. To determine the number of mites per gram, $1 \mathrm{~g}$ of sieved sample dust was weighed in a microbalance and examined for HDMs using the lactic acid precipitation method $(5,20-22)$. The dust sample was placed in a petri dish, and 10 $\mathrm{mL}$ of $90 \%$ lactic acid was added. The petri dish was heated for 30 min on a hot table to $70-80^{\circ} \mathrm{C}$. The mixture was then distributed as thin layers on other petri dishes. The solution was examined under a stereo microscope (Leica EZ4, Switzerland), and the mites were isolated using a thin needle. The collected mites were transferred to Hoyer's medium to create permanent preparations, labeled, and allowed to dry for 7-10 days in an incubator (Binder, Germany) at $50^{\circ} \mathrm{C}$. Mite species were identified under a light microscope equipped with differential interference contrast (DIC; Olympus BX63, Japan) using standard taxonomic keys (5, 23). The permanent mite preparations were stored at the Acarology laboratory of the Department of Biology.

The mean number of mites per gram of dust was calculated by dividing the total number of mites by the number of positive samples.

Statistical analyses were performed using Statistical Package for Social Sciences for Windows, version 18.0 (SPSS Inc.; Chicago, IL, USA). Descriptive statistics were determined for each variable. The normality of the data distribution was assessed using the Kolmogorov-Smirnov test. The results for continuous variables 
were recorded as the mean \pm standard deviation. For continuous variables without normal distribution, the results were demonstrated as median minimum-maximum. For categorical variables, statistically significant differences between the groups were determined using chi-square test. For continuous variables, nonparametric statistics (Mann-Whitney $U$ test) and parametric statistics (t test) were used, as appropriate. A p value $<0.05$ was considered significant.

\section{RESULTS}

\section{Demographic characteristics of patients and controls}

The patient group comprised 15 females and 10 males, with ages ranging 7-65 years. The control group comprised 10 females and 21 males, with ages ranging 17-69 years. Upon clinical examination, all the patients were found to have moderate persistent AA according to the GINA classification, and all the controls were found to have no AA symptoms (Table 1).

\section{Skin and Serological Test Results}

Positive SPT results with Der p were observed in 19 patients (76\%) and 12 controls (38.7\%), with a statistically significant difference between the groups $(p=0.035)$. Positive SPT results with Der $f$ were

Table 1. Age and sex of patients and controls

\begin{tabular}{|l|c|c|c|}
\hline & $\begin{array}{c}\text { Patient group } \\
(\mathbf{n}=\mathbf{2 5})\end{array}$ & $\begin{array}{c}\text { Control group } \\
(\mathbf{n}=\mathbf{3 1})\end{array}$ & $\mathbf{p}$ \\
\hline $\begin{array}{l}\text { Age }(\text { mean } \pm \text { SD), } \\
\text { years }\end{array}$ & $36.04 \pm 18.11$ & $33.90 \pm 15.13$ & $>0.05^{\star}$ \\
\hline Sex & 15 & 10 & \multirow{2}{*}{$>0.05^{\star *}$} \\
\hline Female & 10 & 21 & \\
\hline Male & & & \\
\hline $\begin{array}{l}\text { SD: standard deviation } \\
\text { *Student t test; }{ }^{* *} \text { chi-square test }\end{array}$ & & \\
\hline
\end{tabular}

Table 2. Species and total number of mites in patients' homes and results of SPT and total and specific lgE levels

\begin{tabular}{|c|c|c|c|c|c|c|c|}
\hline \multirow[b]{2}{*}{ Patient no } & \multicolumn{2}{|c|}{ SPT } & \multicolumn{2}{|c|}{$\begin{array}{c}\text { Serum } \\
\text { specific IgE } \\
(\mathrm{kUA} / \mathrm{L})\end{array}$} & \multirow{2}{*}{$\begin{array}{l}\text { Serum } \\
\text { total lgE } \\
(\mathrm{U} / \mathrm{mL})\end{array}$} & \multicolumn{2}{|c|}{ Number of mites in per gram of dust } \\
\hline & Der $p$ & Der $f$ & Der $p$ & Der $f$ & & D. pteronyssinus & D. farinae \\
\hline 1 & - & + & + & + & 70 & 0 & 0 \\
\hline 2 & - & + & - & - & 45.3 & 0 & 0 \\
\hline 3 & - & + & - & + & 287 & 54 & 0 \\
\hline 5 & - & + & - & - & 54.5 & 0 & 0 \\
\hline 6 & + & + & - & - & 21.8 & 1 & 1 \\
\hline 7 & + & - & - & - & 115 & 6 & 0 \\
\hline 8 & + & - & - & - & 42.5 & 56 & 0 \\
\hline 12 & + & + & - & - & 44.2 & 82 & 0 \\
\hline 13 & - & + & - & - & 16.5 & 1 & 0 \\
\hline 14 & + & + & - & - & 5 & 4 & 0 \\
\hline 15 & + & + & - & + & 89.8 & 4 & 0 \\
\hline 16 & - & + & - & - & 21.4 & 9 & 0 \\
\hline 17 & + & + & + & + & 457 & 2 & 0 \\
\hline 18 & + & + & + & + & 178 & 64 & 0 \\
\hline 19 & + & + & - & - & 80.3 & 2 & 0 \\
\hline 20 & + & + & + & + & 279 & 107 & 54 \\
\hline
\end{tabular}


Table 3. Species and total number of mites in control homes and results of SPT and total and specific lgE levels

\begin{tabular}{|c|c|c|c|c|c|c|c|}
\hline \multirow[b]{2}{*}{ Control no } & \multicolumn{2}{|c|}{ SPT } & \multicolumn{2}{|c|}{$\begin{array}{c}\text { Serum } \\
\text { specific lgE } \\
(k \cup A / L)\end{array}$} & \multirow{2}{*}{$\begin{array}{l}\text { Serum } \\
\text { total IgE } \\
(\mathrm{U} / \mathrm{mL})\end{array}$} & \multicolumn{2}{|c|}{ Number of mites in per gram of dust } \\
\hline & Der $p$ & Der $f$ & Der $p$ & Der $f$ & & D. pteronyssinus & D. farinae \\
\hline 1 & - & - & - & - & 80.7 & 0 & 0 \\
\hline 2 & + & - & - & - & 310 & 0 & 0 \\
\hline 3 & - & + & - & - & 19.9 & 0 & 0 \\
\hline 4 & - & + & - & - & 1.7 & 0 & 0 \\
\hline 5 & + & - & - & - & 7.1 & 0 & 0 \\
\hline 6 & + & - & - & - & 56.3 & 0 & 0 \\
\hline 7 & - & + & - & - & 45.7 & 6 & 0 \\
\hline 8 & - & + & - & - & 62.2 & 6 & 0 \\
\hline 9 & - & - & - & - & 10 & 6 & 0 \\
\hline 10 & - & + & - & - & 1.5 & 4 & 0 \\
\hline 11 & - & - & - & - & 11 & 2 & 0 \\
\hline 12 & - & + & - & - & 25.7 & 4 & 3 \\
\hline 13 & - & + & - & - & 16.8 & 3 & 1 \\
\hline 14 & + & - & - & - & 197.5 & 0 & 0 \\
\hline 15 & + & - & - & - & 85.5 & 0 & 0 \\
\hline 16 & - & - & - & - & 9.6 & 2 & 0 \\
\hline 17 & - & - & - & - & 5.1 & 1 & 0 \\
\hline 18 & - & - & - & - & 71.4 & 0 & 0 \\
\hline 19 & + & + & - & - & 10 & 0 & 0 \\
\hline 20 & - & - & - & - & 211.7 & 0 & 0 \\
\hline 21 & + & - & - & - & 39.1 & 8 & 0 \\
\hline 22 & - & - & - & - & 19.5 & 0 & 0 \\
\hline 23 & + & - & - & - & 86.4 & 0 & 0 \\
\hline 24 & - & + & - & - & 8.1 & 0 & 0 \\
\hline 25 & + & - & - & - & 17.6 & 0 & 0 \\
\hline 26 & - & - & - & - & 11 & 0 & 2 \\
\hline 27 & + & - & - & - & 14.9 & 0 & 2 \\
\hline 28 & + & - & - & - & 11.5 & 0 & 0 \\
\hline 29 & - & + & - & - & 20 & 0 & 0 \\
\hline 30 & + & - & - & - & 20 & 0 & 0 \\
\hline 31 & - & - & - & - & 5 & 0 & 0 \\
\hline Total & 42 & 8 & & & & & \\
\hline
\end{tabular}

noted in 18 patients (72\%) and 10 controls (32.2\%), with a statistically significant difference between the groups $(p=0.007)$ (Table 2-4).

Four (16\%) patients showed elevated Der $p$-specific IgE $(p=0.034)$ and $6(24 \%)$ showed elevated Der $f$-specific $\lg E(p=0.005)$. All the controls were Der $p$ and Der $f$ negative. The total IgE level was high in $9(36 \%)$ patients and $3(9.6 \%)$ controls $(p=0.008)$ (Table 2-4).

\section{Microscopic Examination of Dust Samples}

D. pteronyssinus was found in the homes of 21 patients (84\%) and 10 controls (32.2\%; $\mathrm{p}<0.001$ ) (Figure 1, 2). In the homes of patients, 1,013 D. pteronyssinus mites were found (min, 1; max, 542; mean, 48.2/g dust), while in the homes of control subjects, 42 mites were found ( $\min , 1$; $\max , 8$; mean, 4.2/g dust; $\mathrm{p}<0.001$ ). $D$. farinae (Figures 3,4 ) was found in the homes of 4 patients and 4 controls. In the homes of patients, $89 \mathrm{D}$. farinae mites were detected (min, 1; max, 54; mean, 22.2/g dust), and in the homes of 
Table 4. Comparing existence of HDMs in homes and results of skin and serologic tests between patients and controls

\begin{tabular}{|c|c|c|c|}
\hline & $\begin{array}{l}\text { Patient group } \\
(n=25)\end{array}$ & $\begin{array}{c}\text { Control group } \\
(n=31)\end{array}$ & $\mathrm{p}$ \\
\hline Der p SPT positive & 19 & 12 & $0.035^{\star}$ \\
\hline Der p SPT positive and existence of D. pteronyssinus in homes & 18 & 1 & $<0.001^{*}$ \\
\hline Der f SPT positive & 18 & 10 & $0.007^{\star}$ \\
\hline Der f SPT positive and existence $D$. farinae in homes & 4 & 1 & $>0.05^{\star}$ \\
\hline Der p-specific lgE positive & 4 & 0 & $0.034^{*}$ \\
\hline Der p-specific lgE positive and existence of D. pteronyssinus in homes & 3 & 0 & - \\
\hline Der f-specific lgE positive & 6 & 0 & $0.005^{*}$ \\
\hline Der f-specific IgE positive and existence of D. farinae in homes & 1 & 0 & - \\
\hline Total IgE level (U/mL) & $54.50(5-457)$ & $19.50(1.5-310)$ & $0.008^{\star \star}$ \\
\hline Existence of D. pteronyssinus in homes & 21 & 10 & $<0.001^{*}$ \\
\hline Existence of D. farinae in homes & 4 & 4 & $>0.05^{\star}$ \\
\hline Number of D. pteronyssinus in homes & $3(0-542)$ & $0(0-8)$ & $<0.001^{\star *}$ \\
\hline Number of $D$. farinae in homes & $0(0-54)$ & $0(0-3)$ & $>0.05^{\star \star}$ \\
\hline
\end{tabular}

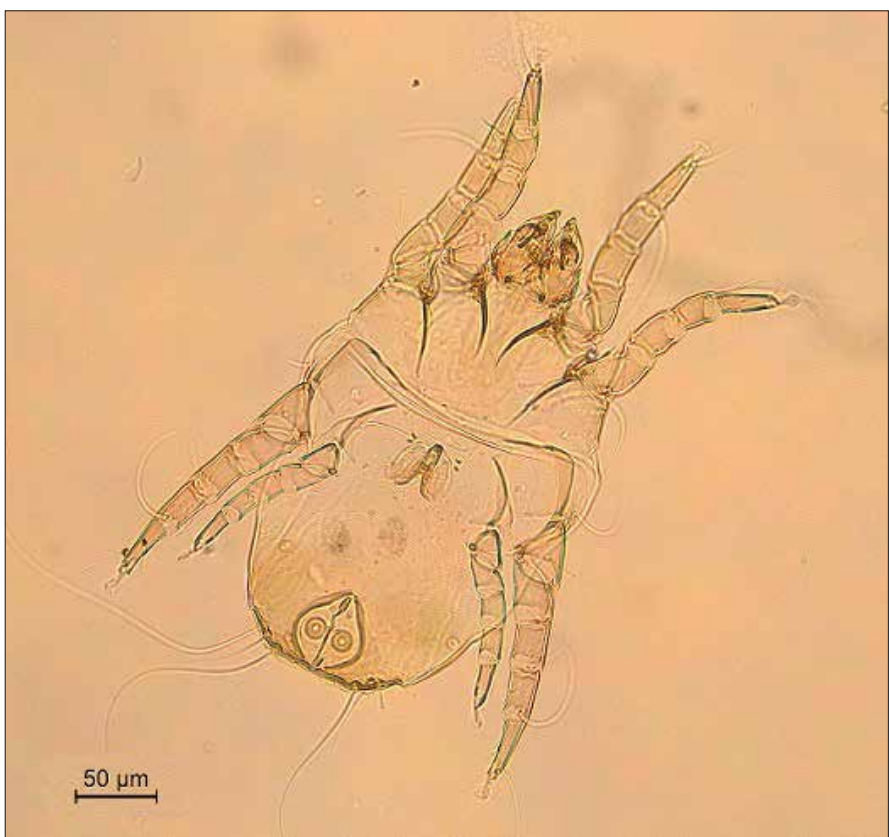

Figure 1. Dermatophagoides pteronyssinus (male)

controls, 8 mites were detected (min, 1; $\max , 3$; mean 2/g dust), and no significant difference was found between the 2 groups (Table 2-4).

D. pteronyssinus was found in the homes of 18 of 19 patients (94.7\%) positive for the Der $\mathrm{p}$ skin test and in 1 of 12 controls (8.3\%) positive for the Der $p$ test $(p<0.001)$. D. farinae was found in of 4 of 18 (22.2\%) patients' homes, who were positive for Der $f$ skin test and (10\%) controls positive for the Der $f$ test, the differences being statistically nonsignificant (Table 2-4).

Der p-specific IgE positivity was detected in $75 \%$ of patients in whose homes D. pteronyssinus was found, while Der f-specific

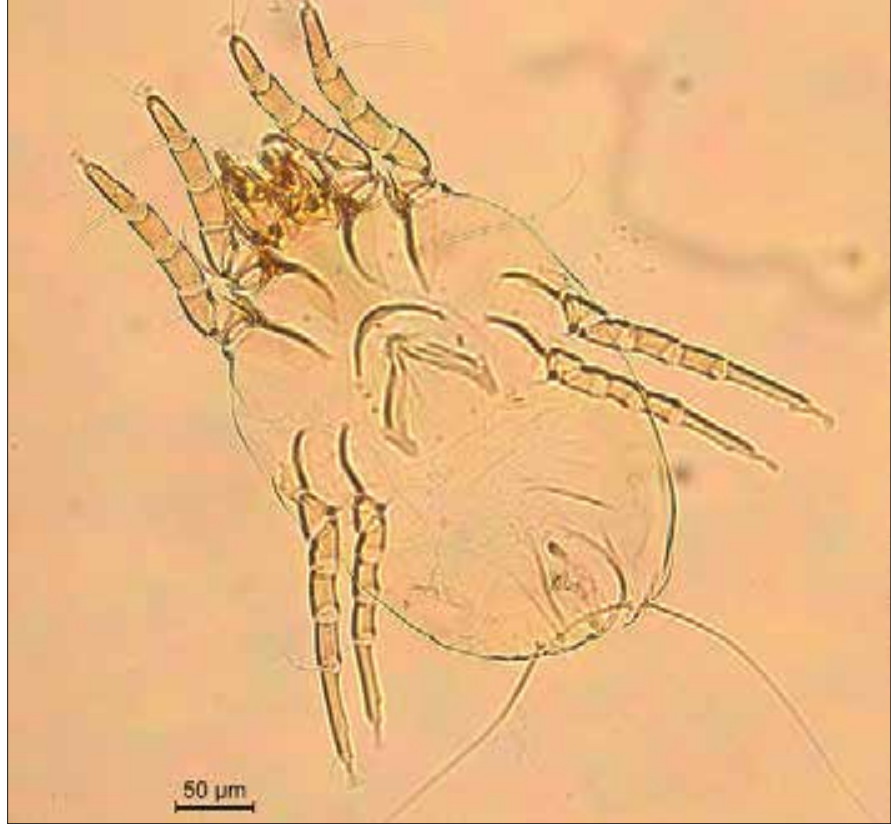

Figure 2. Dermatophagoides pteronyssinus (female)

IgE positivity was detected in $16.6 \%$ of patients in whose homes D. farinae was found. All control subjects were negative for Der $\mathrm{p}$ - and Der f-specific lgE (Table 2-4).

D. pteronyssinus was found in $88.8 \%$ of patients' homes, while D. farinae was found in $11.1 \%$ of patients' homes; these patients had high serum levels of total IgE. The serum level of total lgE was found to be high in 3 controls; however, no D. pteronyssinus or and D. farinae were found in their homes (Table 2, 3).

\section{DISCUSSION}

In addition to the medical history and clinical examination, SPT and determination of allergen-specific IgE are the leading diag- 


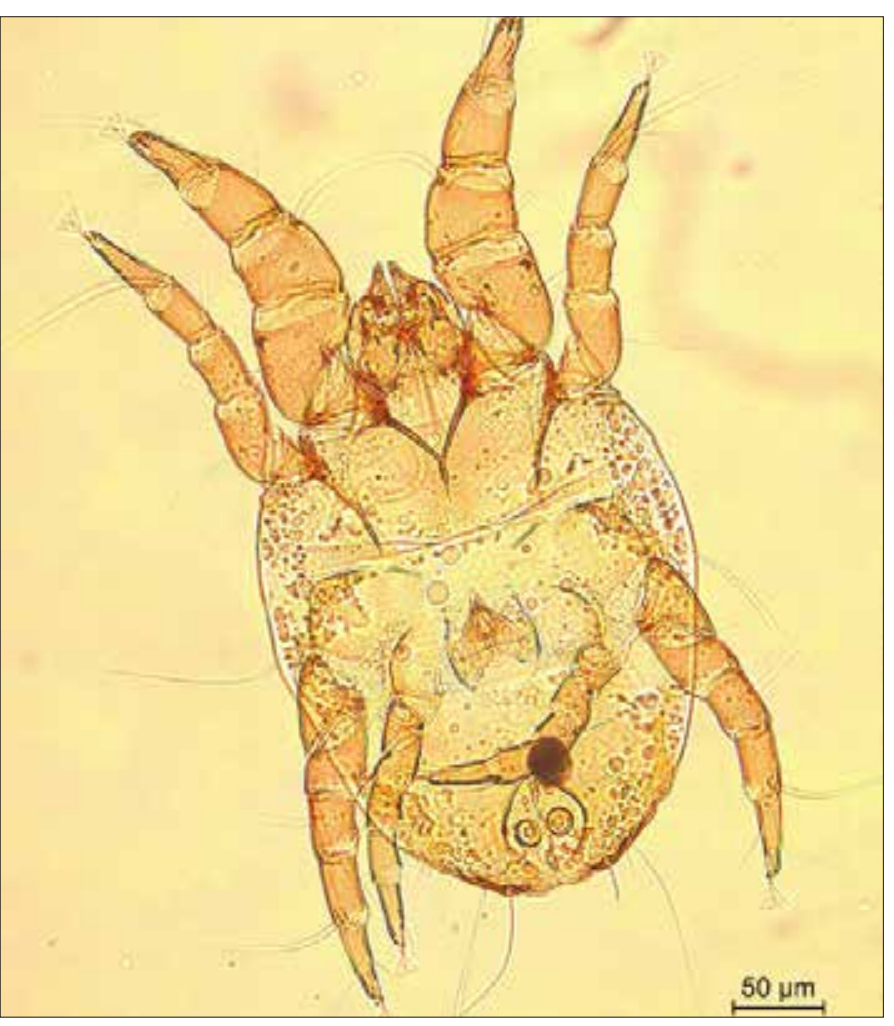

Figure 3. Dermatophagoides farinae (male)

nostic criteria recommended for AA diagnosis (3). In the present study, according to the SPT results, $76 \%$ of AA patients and $38.7 \%$ of control subjects reacted positive to Der $p(p=0.035)$, while $72 \%$ and $32.2 \%$ reacted positive to Der $f(p=0.007)$, respectively. Similar results were obtained for other countries with $77.2 \%$ and $69.5 \%$ in Jakarta, Indonesia; $83 \%$ and $88 \%$ in Monterrey, Mexico; $70 \%$ and $60 \%$ in Irapuato, Mexico; and $55 \%$ and 25\% in Tampico, Mexico; $80.3 \%$ and $83.7 \%$ in Guangzhou, China; $29.8 \%$ and $28 \%$ in Gwangju, South Korea; and 53.2\% and 49.8\% in Yaounde, Cameroon, respectively. Studies conducted in Turkey have reported similar results with $62.2 \%$ and $51.3 \%$ in Eskişehir; $97.1 \%$ and $86.6 \%$ in İmir, respectively, while lower positive tests were obtained in Kocaeli, with $12 \%$ and $11.8 \%$, respectively $(12,14,16-18,24-26)$.

In the present study, elevated Der $\mathrm{p}$ - and Der f-specific IgE levels were reported in $16 \%$ and $24 \%$ of patients, respectively. In Guangzhou, China, positive results were obtained in $61.1 \%$ and $60.2 \%$ of AA patients, and $44 \%$ and $42 \%$ in Connecticut, USA, respectively $(17,27)$. Studies conducted in Turkey have reported high levels of Der $\mathrm{p}$ - and Der f-specific IgE in $79 \%$ and $85 \%$ of patients in Eskişehir and $27.5 \%$ and $17.5 \%$ in Afyon, respectively $(25,28)$. In a study conducted in Kütahya, Der p-specific IgE was detected in $7.3 \%$ of patients, while none of them had Der f-specific IgE (29). The different results obtained could be due to the varying exposure of patients to an HDM in general and to $D$. pteronyssinus and D. farinae in particular. In addition, different extraction procedures and concentrations of Der $p$ and Der $f$ as well as the degree of sensitization of the patients examined could have influenced the results.

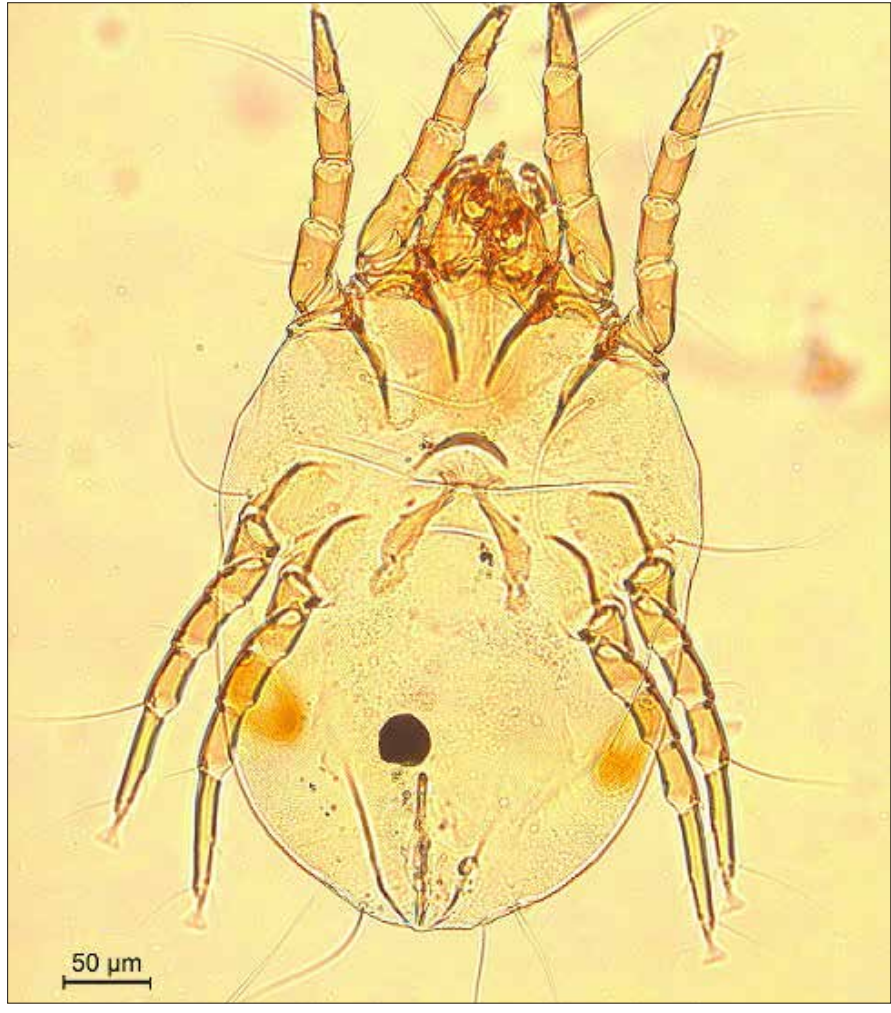

Figure 4. Dermatophagoides farinae (female)

Another serological test used to support clinical findings in the diagnosis of AA is the determination of serum total IgE level. Serum levels of IgE have been reported as elevated in allergic and parasitic diseases (30). In the present study, total IgE levels were high in $36 \%$ of AA patients. Similar studies in other countries have reported high levels of total IgE in $37.8 \%$ of AA patients in Finland and $43.6 \%$ in Russia. Studies from Turkey have reported high levels of serum total $\mathrm{IgE}$ in $56 \%$ of AA patients in Isparta, $19.8 \%$ in Afyon, and $31.9 \%$ in Izmir $(11,31-33)$.

In our study, D. pteronyssinus was found in the homes of 18/19 patients (94.7\%) who were positive for Der $p$ in the skin test $(p<0.001)$. D. farinae was found in the homes of $4 / 18(22.2 \%)$ patients who were positive for Der $f$ in the skin test $(p>0.05)$. $D$. pteronyssinus-specific lgE was detected in 3/4 (75\%) patients in whose homes $D$. pteronyssinus was also found, while $D$. farinae-specific IgE was detected in $1 / 6$ (16.6\%) patients in whose homes $D$. farinae was also found. A positive Der $p$ skin test or Der p-specific lgE was detected in 18/21 (85.7\%) patients whose homes contained $D$. pteronyssinus, while either a positive Der $f$ skin test or Der f-specific IgE was detected in all 4 patients whose homes contained D. farinae. Der $p$ or Der $f$ sensitization in those patients whose homes did not contain $D$. pteronyssinus or $D$. farinae may be the result of cross-reactivity, which is noted in various studies in the literature $(5,8,34-37)$. In $84 \%$ of the AA patients who were sensitive to Der $p$ and/or Der $f$ allergen, $D$. pteronyssinuss and/or D. farinae were found in their homes (Table 2). A combination of skin and serological tests as well as acarological examination of the dust samples from the patient's home could provide important indications regarding the sensitization of the patients to HDM. 
Acarological studies conducted in the homes of AA patients have reported D. pteronyssinus and D. farinae in $75 \%$ and $25 \%$ of patients in Nigeria; $44.4 \%$ and $55.5 \%$ in Italy, and $77 \%$ and $13 \%$ in Taiwan, respectively. Studies conducted in Spain have reported 99\% and $15 \%$ of patients' homes in Tenerife, $98.2 \%$ and $5.5 \%$ in La Coruna, $98.8 \%$ and $4.8 \%$ in Lugo, $93.3 \%$ and $6.7 \%$ in Ourense, $100 \%$ and $2.2 \%$ in Pontevedra, and $31.8 \%$ and $35.6 \%$ in Murcia with $D$. pteronyssinus and D. farinae, respectively. Studies in Turkey have reported the presence of $D$. pteronyssinus in the homes of $27.5 \%$ of patients with allergic suspicion in Afyon, $46.3 \%$ in Malatya, and $18.8 \%$ in Kütahya, while D. farinae was not detected in these homes $(10,13,29,32,38-42)$. However, faunistic studies of HDM conducted in 7 geographic regions of Turkey showed the presence $(0.2 \%-15 \%)$ of $D$. farinae in the homes of healthy individuals $(22,43-47)$. The present study showed for the first time that $D$. farinae is present in the house of AA patients.

\section{CONCLUSION}

In conclusion, the present study revealed that a part of AA patients residing in Erzincan are sensitized to HDMs and that their homes contain high numbers of HDM. Therefore, preventive measures in patients' homes may be beneficial.

Ethics Committee Approval: Ethics committee approval was received for this study from Ethics Commity of Erzincan University (2014-02/6).

Informed Consent: Written informed consent was obtained from participants of this study.

Peer-review: Externally peer-reviewed.

Author contributions: Concept - E.Z., S.D., F.Ö., E.Ü.; Design - E.Z., S.D.; Supervision - S.D.; Resource - E.Z.; Materials - E.Z., S.D.; Data Collection and/ or Processing - E.Z.; Analysis and /or Interpretation - E.Z., S.D., F.Ö., E.Ü.; Literature Search - E.Z.; Writing - E.Z., F.Ö.; Critical Reviews - S.D., F.Ö.,E.Ü.

Acknowledgements: The authors would like to thank all the residents who opened their home to them and to anonymous reviewers and copy editors for their constructive suggestions.

Conflict of Interest: No conflict of interest was declared by the authors.

Financial Disclosure: This study was supported by a Research Fund of the Erzincan University (EUBAP-FEN-A-300614-0107).

Etik Komite Onayı: Bu çalışma için etik komite onayı Erzincan Üniversitesi Etik Kurulu'ndan alınmıştır (2014-02/6).

Hasta Onamı: Yazılı hasta onamı bu çalışmanın katılımcılarından alınmıştır.

Hakem Değerlendirmesi: Dış Bağımsız.

Yazar Katkıları: Fikir - E.Z., S.D., F.Ö., E.Ü.; Tasarım - E.Z., S.D.; Denetleme - S.D.; Kaynaklar - E.Z.; Malzemeler - E.Z., S.D.; Veri Toplanması ve/ veya işlemesi - E.Z.; Analiz ve/veya Yorum - E.Z., S.D., F.Ö., E.Ü.; Literatür taraması - E.Z.; Yazıyı Yazan - E.Z., F.Ö.; Eleştirel İnceleme - S.D., F.Ö.,E.Ü.

Teşekkür: Yazarlar, kendilerine evlerini açan tüm ev sakinlerine ve bu çalışmayı değerlendiren anonim hakemler ve editöre yapıcı önerileri için teşekkür ederler

Çıkar Çatışması: Yazarlar çıkar çatışması bildirmemişlerdir.

Finansal Destek: Bu çalışma Erzincan Üniversitesi Bilimsel Araştırma Projeleri Koordinatörlüğü tarafından desteklenmiştir (EUBAP - FEN-A 300614-0107).

\section{REFERENCES}

1. Yalçin $S$, Yeğin $O$, Mutlu G, Unal S. The effect of immunotherapy on lymphocyte subsets and autologous rosette formation in allergic asthmatic patients. Mikrobiyol Bul 1990; 24: 314-20

2. Bavbek S, Mungan D, Türktaş H, Mısırlıgil Z, Gemicioğlu B. A costof-illness study estimating the direct cost per asthma exacerbation in Turkey. Respir Med 2011; 105: 541-8. [CrossRef]

3. GINA (Global Initiative for Asthma), Global strategy for asthma management and prevention. Available at: URL: http://www.ginasthma. org.

4. Stewart GA, Bird CH, Krska KD, Colloff MJ, Thompson PJ. A comparative study of allergenic and potentially allergenic enzymes from Dermatophagoides pteronyssinus, D. farinae and Euroglyphus maynei. Exp Appl Acarol 1992; 16: 165-80. [CrossRef]

5. Colloff MJ. Dust mites. Csiro Publishing, New Zealand and Australia. 2009. [CrossRef]

6. Jeong KY, Kim C, Yong TS. Enzymatic activities of allergen extracts from three species of dust mites and cockroaches commonly found in Korean home. Korean J Parasitol 2010; 48: 151-5. [CrossRef]

7. Calderón MA, Linneberg A, Kleine-Tebbe J, De Blay F, Hernandez Fernandez de Rojas D, Virchow JC, et al. Respiratory allergy caused by house dust mites: What do we really know? J Allergy Clin Immunol 2015; 136: 38-48. [CrossRef]

8. Roche N, Chinet TC, Huchon GJ. Allergic and nonallergic interactions between house dust mite allergens and airway mucosa. Eur Respir J 1997; 10: 719-26.

9. Gaffin JM, Phipatanakul W. The role of indoor allergens in the development of asthma. Curr Opin Allergy Clin Immunol 2009; 9: 128-35. [CrossRef]

10. Sun HL, Lue KH. Household distribution of house dust mite in central Taiwan. J Microbiol Immunol Infect 2000; 33: 233-6.

11. Vartiainen E, Petäys T, Haahtela T, Jousilahti P, Pekkanen J. Allergic diseases, skin prick test responses, and IgE levels in North Karelia, Finland, and the Republic of Karelia, Russia. J Allergy Clin Immunol 2002; 109: 643-8. [CrossRef]

12. Sundaru $\mathrm{H}$. House dust mite allergen level and allergen sensitization as risk factors for asthma among student in Central Jakarta. Med J Indones 2006; 15: 55-9. [CrossRef]

13. Atambay M, Aycan OM, Yoloğlu S, Karaman U, Daldal N. The relationship between the skin allergy test and house dust mites. Turkiye Parazitol Derg 2006; 30: 327-9.

14. Cavazos Galván M, Guerrero Núñez B, Ramírez Aragón D. Comparative mites and cockroaches sensitization study in three cities of Mexico. Rev Alerg Mex 2008; 55: 234-9.

15. Akdemir C, Soyucen ES. Sensitization of children to storage mites in Kutahya, Turkey. Korean J Parasitol 2009; 47: 387-91. [CrossRef]

16. Sönmez Tamer G, Calişkan S. Prevalence of house dust mite allergy in cases with atopic disease symptoms in Kocaeli province, Turkey. Mikrobiyol Bul 2009; 43: 309-12. (

17. Zhang C, Li J, Lai X, Zheng Y, Gjesing B, Spangfort MD, et al. House dust mite and storage mite IgE reactivity in allergic patients from Guangzhou, China. Asian Pac J Allergy Immunol 2012; 30: 294-300.

18. Pefura-Yone EW, Kengne AP, Kuaban C. Sensitisation to mites in a group of patients with asthma in Yaounde, Cameroon: a cross-sectional study. BMJ Open 2014; 4: e004062. [CrossRef]

19. Heinzerling L, Mari A, Bergmann KC, Bresciani M, Burbach G, Darsow $U$, et al. The skin prick test - European standards. Clin Transl Allergy 2013; 3: 3. [CrossRef]

20. Spieksma FT, Spieksma-Boezeman MI. The mite fauna of house dust with particular reference to the house dust mite Dermatophagoides pteronyssinus (Trouessart, 1897) (Psoroptidae: Sarcoptiformes). Acarologia 1967; 9: 226-41. 
21. Zeytun E, Doğan S, Aykut M, Özçiçek F, Ünver E, Özçiçek A. House dust mites in Erzincan province. Turkiye Parazitol Derg 2015; 39: 124 30. [CrossRef]

22. Zeytun E, Dogan S, Ozcicek F, Unver E, Dilkaraoglu S. Comparison of living and bedrooms in terms of house dust mites in the province of Erzincan, Turkey. J Med Entemol 2016; 53: 26-30. [CrossRef]

23. Krantz GW, Walter DE. A manual of acarology. Texas Tech Univerity Press, Lubbock, TX. 2009.

24. Choi IS, Lee SS, Myeong E, Lee JW, Kim WJ, Jin J. Seasonal variation in skin sensitivity to aeroallergens. Allergy Asthma Immunol Res 2013; 5: 301-8. [CrossRef]

25. Harmanci E, Us T, Ozdemir N, Akgun Y, Aydınlı A, Mutlu S. The relationship between skin prick tests and serum specific lgE which is determined by chemiluminescence method in the diagnosıs of respiratory system allergies. Solunum 2000; 31-5.

26. Olmez D, Babayigit A, Uzuner N, Karaman O, Tezcan D, Kose S. Retrospective evaluation of the patients sensitized with house dust mite. Dokuz Eylül Üniversitesi Tıp Fakültesi Dergisi 2005; 19: 77-83.

27. Gent JF, Kezik JM, Hill ME, Tsai E, Li DW, Leaderer BP. Household mold and dust allergens: exposure, sensitization and childhood asthma morbidity. Environ Res 2012; 118: 86-93. [CrossRef]

28. Ciftci IH, Çetinkaya Z, Aktepe OC, Kıyıldı N, Aycan OM, Atambay M et al. The relation between house dust allergens and specific IgE. Med J Kocatepe 2004; 5: 29-32.

29. Akdemir C, Yilmaz S. Sensitization to house-dust mite and mite fauna in selected children's homes in Kütahya, Turkey. Turk J Pediatr 2009; 51: 232-7.

30. Bousquet J, Khaltaev N, Cruz AA, Denburg J, Fokkens W, Togias A, et al. Allergic rhinitis and its impact on asthma (ARIA) 2008 update (in collaboration with the World Health Organization, GA(2)LEN and AllerGen). Allergy 2008; 86: 8-160. [CrossRef]

31. Akkaya A, Ünlü M, Uygun N. Evoluation of prick test positivity and total IgE levels in cases with allergic asthma and allergic rhinitis in Isparta district. Süleyman Demirel Üniversitesi Tıp Fakültesi Dergisi 1995; 2: 29-32.

32. Ciftci IH, Cetinkaya Z, Aktepe $\mathrm{O}, \mathrm{K}$ ıyıldı N, Altındis M. The distribution of allergens in the Afyon region. Asthma Allergy Immunol 2005; 3: 5-9.

33. Yilmaz N, Can D, Asilsoy S, Gulle S. The diagnostic value of specific IgE in allergic diseases. Asthma Allergy Immunol 2009; 7: 111-7.

34. Arlian LG. House dust mite allergens: a review. Exp Appl Acarol 1991; 10: 167-86. [CrossRef]
35. Arlian LG, Morgan MS, Vyszenski-Moher DL, Sharra D. Cross-reactivity between storage and dust mites and between mites and shrimp. Exp Appl Acarol 2009; 47: 159-72. [CrossRef]

36. Johansson E, Johansson SG, Hage-Hamsten M. Allergenic characterization of Acarus siro and Tyrophagus putrescentiae and their crossreactivity with Lepidoglyphus destructor and Dermatophagoides pteronyssinus. Clin Exp Allergy 1994; 24: 743-51. [CrossRef]

37. García-Robaina JC, Eraso E, De la Torre F, Guisantes J, Martinez A, Palacios $R$, et al. Extracts from various mite species contain cross-reactive and noncross-reactive lgE epitopes. A RAST inhibition study. J Invest Allerg Clin Immunol 1997; 8: 285-9.

38. Somorin AO, Hunponu-Wusu OO, Mumcuoglu Y, Heiner DC. Mite allergy in Nigerians: studies on house dust mites in houses of allergic patients in Lagos. Irısh J Med Sci 1978; 147: 26-30. [CrossRef]

39. Bigliocchi F, Maroli M. Distribution and abundance of house dust mites (Acarina: Pyroglyphidae) in Rome, Italy. Int J Aerobiol 1995; 11: 35-40. [CrossRef]

40. Sanchez-Covisa A, Rodriguez-Rodriguez JA, De la Torre F, Garcia-Robaina JC. Mite fauna of house dust of the island of Tenerife. Acarologia 1999; 40: 55-8.

41. Boquete M, Iraola V, Fernandez-Caldas E, Villaroel LA, Carballada FJ, de la Cuesta CG et al. House dust mite species and allergen levels in Galicia, Spain: a cross-sectional, multicenter, comparative study. J Invest Allerg Clin 2006; 16(3): 169-176.

42. Pagan JA, Huertas AJ, Iraola V, Pinto H, Martinez R, Ramirez M, et al. Mite exposure in a Spanish Mediterranean region. Allergol Immunopath 2012; 40: 92-9. [CrossRef]

43. Kalpaklioglu AF, Emekçi M, Ferizli AG, Misirligil Z. House dust mite fauna in Turkey. J Investig Allergol Clin Immunol 1997; 7: 578-82.

44. Kalpaklioğlu AF, Emekçi M, Ferizli A, Misirligil Z. A survey of acarofauna in Turkey: comparison of seven different geographic regions. Allergy Asthma Proc 2004; 25: 185-90.

45. Güleğen E, Gırısgın $O$, Kütükoğlu F, Gırışgın AO, Coşkun SZ. Mite species found in house dust in houses in Bursa. Turkiye Parazitol Derg 2005; 29: 185-7.

46. Ciftci IH, Cetinkaya Z, Atambay M, Kiyildi N, Aycan OM, Daldal N. House dust mite fauna in western Anatolia, Turkey. Korean J Parasitol 2006; 44: 259-64. [CrossRef]

47. Aykut M, Erman OK, Doğan S, Ayyıldız N. House dust mites of Bitlis and Muş provinces. Turkish Bulletin of Entomology 2013; 3: 169-77. 